\title{
Author Correction: Super-regional land-use change and effects on the grassland specialist flora
}

\author{
Alistair G. Auffret (10) 1,2,3, Adam Kimberley (10 ${ }^{2}$, Jan Plue (10 ${ }^{2,4}$ \& Emelie Waldén (1) ${ }^{2}$ \\ Correction to: Nature Communications https://doi.org/10.1038/s41467-018-05991-y, published online 27 August 2018.
}

The original version of this Article contained an error in Fig. 1a, in which the change in landscape heterogeneity was incorrectly plotted instead of the intended variable, the change in open land-cover. The data were described correctly in the "Results" text and figure legend of the original article. This has been corrected in both the PDF and HTML versions of the Article.

Published online: 19 September 2019

Open Access This article is licensed under a Creative Commons Attribution 4.0 International License, which permits use, sharing, adaptation, distribution and reproduction in any medium or format, as long as you give appropriate credit to the original author(s) and the source, provide a link to the Creative Commons license, reproduction in any medium or format, as long as you give appropriate credit to the original author(s) and the source, provide a link to the Creative Commons license,
and indicate if changes were made. The images or other third party material in this article are included in the article's Creative Commons license, unless indicated otherwise in a credit line to the material. If material is not included in the article's Creative Commons license and your intended use is not permitted by statutory regulation or exceeds the permitted use, you will need to obtain permission directly from the copyright holder. To view a copy of this license, visit http://creativecommons.org/licenses/by/4.0/.

(c) The Author(s) 2019

\footnotetext{
${ }^{1}$ Department of Ecology, Swedish University of Agricultural Sciences, Box 704475007 Uppsala, Sweden. ${ }^{2}$ Biogeography and Geomatics, Department of Physical Geography, Stockholm University, 10691 Stockholm, Sweden. ${ }^{3}$ Department of Biology, University of York, York YO10 5DD, UK. ${ }^{4}$ School for Natural Sciences, Technology and Environmental Studies, Södertörn University, 14189 Stockholm, Sweden. Correspondence and requests for materials should be addressed to A.G.A. (email: alistair.auffret@slu.se)
} 